\title{
Budesonide and formoterol inhibit ICAM-1 and VCAM-1 expression of human lung fibroblasts
}

\author{
F.M. Spoelstra*, D.S. Postma**, H. Hovenga*, J.A. Noordhoek**, H.F. Kauffman*
}

Budesonide and formoterol inhibit ICAM-1 and VCAM-1 expression of human lung fibroblasts. F.M. Spoelstra, D.S. Postma, H. Hovenga, J.A. Noordhoek, H.F. Kauffman. (C) ERS Journals Ltd 2000.

ABSTRACT: The glucocorticoid budesonide and the long-acting $\beta_{2}$-adrenoceptor agonist formoterol are used in asthma therapy for their anti-inflammatory and bronchodilating effects, respectively. Since expression of adhesion molecules on resident cells in the lung plays an important role in asthmatic inflammatory responses, the effects of these drugs on the cytokine-induced intercellular adhesion molecule-1 (ICAM)-1 and vascular cell adhesion molecule-1 (VCAM)-1 expression of human lung fibroblasts were investigated.

Budesonide and formoterol were added in the absence or presence of interleukin (IL)-1 $\beta$, tumour necrosis factor- $\alpha$ (TNF- $\alpha$ ), interferon gamma (IFN- $\gamma$ ) or IL-4 to human lung fibroblasts; ICAM-1 and VCAM-1 expression were measured after $8 \mathrm{~h}$ using a cell surface enzyme linked immunosorbent assay (ELISA).

It was found that both budesonide and formoterol significantly inhibited $(p<0.05)$ the increased expression of ICAM-1 and VCAM-1 after stimulation with IL-1 $\beta$ (maximal inhibition (median (25-75\% percentiles) 50 (48-52) and 61\% (42-69), respectively, with budesonide and $55(50-73)$ and $86 \%(64-94)$, respectively, with formoterol $\left(10^{-7} \mathrm{M}\right)$ ), TNF- $\alpha$ (maximal inhibition 49 (46-57) and $57 \%(44-68)$, respectively, with budesonide and $44(40-75)$ and $62 \%(52-83)$ respectively, with formoterol), IFN- $\gamma$ (maximal inhibition 64\% (41-67) with budesonide and $39 \%$ (29-49) with formoterol for ICAM-1) and IL-4 (maximal inhibition 82\% (69-92) with budesonide and $43 \%(33-67)$ with formoterol for VCAM-1) in a dose-dependent manner.

The results show that budesonide, as well as formoterol, in probably clinically relevant concentrations inhibits cytokine-induced adhesion molecule expression on human lung fibroblasts from a concentration of $10^{-9} \mathrm{M}$. This inhibitory effect on resident cells may have implications for the infiltration of inflammatory cells into pulmonary tissue during therapy with these drugs in asthma.

Eur Respir J 2000; 15: 68-74.

Glucocorticoids and $\beta_{2}$-agonists are currently used extensively in the treatment of asthma. The glucocorticoid budesonide is used for its anti-inflammatory properties, resulting, for instance, in a reduced number of eosinophils in sputum and in peripheral blood after allergen challenge [1]. A main target of glucocorticoid action is inhibition of inflammatory cell activation, demonstrated for T-cell proliferation [2], blood mononuclear cell cytokine production [3] and eosinophil chemokine production and survival $[4,5]$. More recently, it has become apparent that glucocorticoids also exhibit inhibitory effects on the activation of resident cells in the lung. Budesonide, as well as dexamethasone, is able to inhibit the cytokine production and adhesion molecule expression of endothelial and epithelial cells [6,7], and the cytokine production of smooth muscle cells [8] and fibroblasts [9].

The $\beta_{2}$-agonist formoterol, mainly used in asthma therapy for its long-acting bronchodilating effect, can also inhibit allergic inflammation, probably by increasing intracellular cyclic adenosine monophosphate (cAMP) levels [10]. The inhibitory effects of long-acting $\beta_{2}$-agonists on
*Dept of Allergology, **Dept of Pulmonology. University Hospital Groningen, Groningen, the Netherlands.

Correspondence: H.F. Kauffman

Laboratory of Allergology

Clinic for Internal Medicine

University Hospital Groningen

Hanzeplein 1

9713 GZ Groningen

The Netherlands

Fax: 31503121576

Keywords: Adhesion molecules

budesonide

formoterol

lung fibroblasts

Received: May 41999

Accepted after revision September 281999

This study was supported by a grant Astra Zeneca, Zoetermeer, the Netherlands. eosinophils and other inflammatory cells have been described $[11,12]$. Some in vivo studies in humans show inhibitory effects of formoterol on the late asthmatic response (LAR), but do not show decreased eosinophil numbers in blood and sputum $[13,14]$. However, WALLIN et al. [15] found a reduced number of submucosal eosinophils in patients with more severe airway inflammation after treatment with inhaled formoterol. In guinea-pigs, formoterol inhibits the LAR as well as the eosinophilic influx [16]. In addition, formoterol is able to inhibit granulocyte adhesion to vascular endothelium in vitro [17].

The infiltration of activated eosinophils into bronchial as well as peripheral lung tissue, along with other inflammatory cells $[18,19]$, is dependent on chemotactic stimuli and adhesion phenomena. Fibroblasts, resident cells of the connective tissue, are able to secrete a variety of inflammatory cytokines and chemokines $[20,21]$ as well as expressing intercellular adhesion molecule-1 (ICAM-1) and vascular cell adhesion molecule-1 (VCAM-1). These adhesion molecules are upregulated after cytokine exposure, with differential roles for interferon gamma (IFN- $\gamma$ ), 
selectively upregulating ICAM-1 expression, and interleukin (IL)-4, selectively upregulating VCAM-1 expression $[22,23]$. They both have been demonstrated to play a role in polymorphonuclear leukocyte transmigration over fibroblasts [24] and T-cell adhesion to fibroblasts in vitro [25]. Eosinophils have been shown at least to adhere to fibroblasts via an ICAM-1-dependent mechanism [26], but are known to express very late activation antigen-4, which adheres to fibronectin and VCAM-1 and could be responsible for the selective eosinophil infiltration into tissue compared to that of neutrophils [27]. Thus, lung fibroblasts may be important regulators of inflammatory cell infiltration in asthma.

The beneficial effects of budesonide and formoterol on clinical parameters in asthma can partly be attributed to modulation of adhesion molecule expression on resident lung tissue cells. In the present study, the effect of the glucocorticoid budesonide and the $\beta_{2}$-agonist formoterol on ICAM-1 and VCAM-1 expression on human lung fibroblasts in vitro, as induced by the inflammatory cytokines IL-1 $\beta$, tumour necrosis factor- $\alpha$ (TNF- $\alpha)$, IFN- $\gamma$ or IL-4, was investigated.

\section{Materials and methods}

\section{Fibroblast culture}

Pulmonary parenchyma was obtained from bilobar lung resection material (part of healthy lobe) after oncological surgery in a nonasthmatic individual. The tissue was cultured using the explant technique. Fibroblasts were cultured in Ham's F12 medium (BioWhittaker Verviers, Belgium), supplemented with $10 \%$ foetal calf serum (Bodinko, Alkmaar, the Netherlands), $125 \mathrm{U} \cdot \mathrm{mL}^{-1}$ sodium penicillin G (Yamanouchi Pharma, Leiderdorp, the Netherlands) and $125 \mu \mathrm{g} \cdot \mathrm{mL}^{-1}$ streptomycin sulphate (RadiumEarma-Fisiopharma, Milan, Italy), hereafter referred to as Ham's complete medium. Fibroblast passage was performed by means of trypsinization with trypsin/ethylenediamine tetra acetic acid (BioWhittaker). Passage was carried out in a 1:4 ratio, the cells grown to confluence (passage 5) in 6-7 days microscopic examination) in 96-well culture plates (Costar Europe, Badhoevedorp, the Netherlands) and used for experiments. Fibroblast characterization was performed with antibodies directed against vimentin, cytokeratin, desmin, smooth muscle actin and fibronectin using fluorescence microscopy. Fibroblast purity was $>98 \%$, the only contaminating cells being smooth muscle cells. As a control for heterogeneity of fibroblasts derived from different donor tissue, fibroblast cultures derived from the pulmonary parenchyma of three other donors were also assessed: comparable inhibitory effects of the drugs were seen.

\section{Drugs}

Budesonide was obtained from a Pulmicort Turbuhaler (Astra Pharmaceutica, Zoetermeer, the Netherlands) and dissolved in $96 \%$ ethanol at a concentration of $10^{-2} \mathrm{M}$. Subsequently, solutions of $10^{-10}-10^{-7} \mathrm{M}$ budesonide were prepared in Ham's complete medium. Formoterol fumarate dihydrate (Astra Draco, Lund, Sweden) was dissolved in dimethyl sulphoxide at a concentration of $10^{-2} \mathrm{M}$. Working solutions $\left(10^{-10}-10^{-7} \mathrm{M}\right)$ were prepared in Ham's complete medium. The viability of confluent fibroblasts after incubation with different concentrations of budesonide and formoterol was assessed using trypan blue exclusion and was always $>95 \%$.

\section{Incubations}

Confluent fibroblast layers in 96-well plates were preincubated for $30 \mathrm{~min}$ with different concentrations of budesonide or formoterol, followed by an 8-h stimulation with $1 \mathrm{U} \cdot \mathrm{mL}^{-1} \mathrm{IL}-1 \beta$ (Boehringer Mannheim, Mannheim, Germany), $100 \mathrm{U} \cdot \mathrm{mL}^{-1}$ TNF- $\alpha$ (Genzyme, Cambridge, MA, USA), $2 \mathrm{U} \cdot \mathrm{mL}^{-1} \mathrm{IFN}-\gamma, 5 \mathrm{ng} \cdot \mathrm{mL}^{-1} \mathrm{IL}-4$ (Boehringer Mannheim) or Ham's complete medium (control) in the presence of the same concentration of drug (total volume $100 \mu \mathrm{L})$. In a previous study, it was shown that IL- $1 \beta$ and TNF- $\alpha$ were able to induce both ICAM- 1 and VCAM-1 upregulation, whereas IFN- $\gamma$ specifically induced ICAM-1 and IL-4 specifically induced VCAM-1 upregulation [23]; maximal expression was reached after approximately $8 \mathrm{~h}$ of stimulation. Vehicle controls were assessed for drug concentrations of $10^{-8} \mathrm{M}$ and $10^{-7} \mathrm{M}$ and did not influence ICAM-1 or VCAM-1 upregulation (data not shown). After incubation with cytokines, fibroblasts were washed twice with cold phosphate-buffered saline (PBS) supplemented with $0.01 \% \mathrm{CaCl}_{2}$, and fixed for $10 \mathrm{~min}$ in $96 \%$ ethanol at $4{ }^{\circ} \mathrm{C}$. Fibroblasts were dried on air for $30 \mathrm{~min}$ and stored at $4{ }^{\circ} \mathrm{C}$ for a maximum of 14 days until determination of adhesion molecule expression.

\section{Cell surface enzyme-linked immunosorbent assay}

Determination of ICAM-1 and VCAM-1 expression was performed using a modified cell surface enzyme-linked immunosorbent assay according to PIELA SMITH et al. [28]. Briefly, fibroblast layers were incubated with $1 \%$ bovine serum albumin (Merck, Darrnstadt, Germany) in PBS for $1 \mathrm{~h}$ to block nonspecific binding sites. The cells were incubated with anti-ICAM-1 $\left(2 \mu \mathrm{g} \cdot \mathrm{mL}^{-1}\right)$, anti-VCAM-1 $\left(10 \mu \mathrm{g} \cdot \mathrm{mL}^{-1}\right)(\mathrm{R} \& \mathrm{D}$ Systems, Abingdon, UK) or immunoglobulin $\mathrm{G} 1$ (IgG1) isotype control $\left(4 \mu \mathrm{g} \cdot \mathrm{mL}^{-1}\right)($ Centraal Laboratorium van de Bloedtransfusiedienst, Amsterdam, the Netherlands) for $120 \mathrm{~min}$ at room temperature $\left(20^{\circ} \mathrm{C}\right)$, washed according to a five-step washing procedure performed by a Microplate Strip Washer (Bio-Tek Instruments, Burlington, NJ, USA) and incubated with $50 \mu \mathrm{L}$ horseradish peroxidase-conjugated rabbit anti-mouse antibody (DAKO, Glostrup, Denmark; 1:500) for $30 \mathrm{~min}$. After the second washing procedure, $200 \mu \mathrm{L}$ substrate solution containing $1.25 \mathrm{mg} \cdot \mathrm{mL}^{-1} o$-phenylene diamine dihydrochloride (Sigma Chemical CO, St Louis, MO, USA) was added and colour development was stopped after $30 \mathrm{~min}$ by the addition of $50 \mu \mathrm{L} 3 \mathrm{M} \mathrm{H}_{2} \mathrm{SO}_{4}$. The absorbance (optical density (OD)) at $490 \mathrm{~nm}$ was measured using a microplate reader supported by SoftmaxPro software (Molecular Devices, Sunnyvale, CA, USA).

\section{Data analysis}

ICAM-1 and VCAM-1 expressions were calculated from the mean OD (at $490 \mathrm{~nm}$ ) of quadruplicate determinations within one experiment after subtraction of the OD of the 
IgG1 isotype control. Coefficients of variation were not $>10 \%$; outlying ODs within quadruplicates were only left out when they exceeded 2SD of the mean. At least five separate experiments for each cytokine stimulation were performed. To evaluate the dose-dependent effects of budesonide and formoterol, the mean ODs of the quadruplicate determinations representing ICAM-1 and VCAM-1 expression were analysed using the Friedman test. To further evaluate statistical differences between samples, the nonparametric Wilcoxon signed-rank test for related samples was used. Differences were considered significant at $\mathrm{p}<0.05$. Percentages of inhibition are presented as medians with $25-75 \%$ percentiles in parentheses.

\section{Results}

\section{Effects of budesonide}

Budesonide and formoterol both inhibited all cytokineinduced upregulation of ICAM-1 and VCAM-1 on human lung fibroblasts. IL-1 $\beta$ upregulated ICAM-1 and VCAM-1 expression after $8 \mathrm{~h}$ of stimulation by 708 and $213 \%$ compared to baseline, respectively.
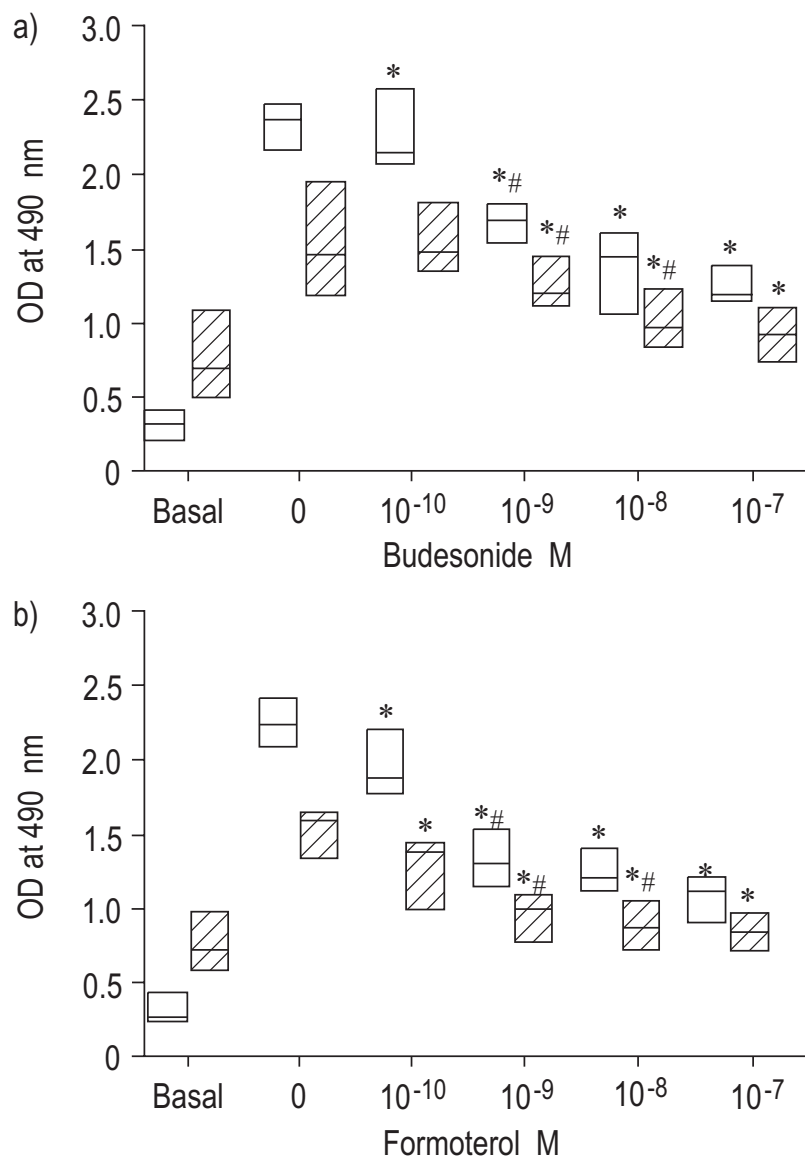

Fig. 1. - Effect of: a) budesonide at $10^{-10}-10^{-7} \mathrm{M}(\mathrm{n}=7)$; and $\left.\mathrm{b}\right)$ formoFig. 1. - Effect of: a) budesonide at $10^{-10}-10^{-7} \mathrm{M}(\mathrm{n}=7)$; and b) formocellular adhesion molecule-1 $(\square)$ and vascular cell adhesion molecule-1 $(\mathbb{Z})$ expression of human lung fibroblasts. Data are presented as median and $25-75 \%$ percentiles after subtraction of isotype control. OD: optical density. *: $\mathrm{p}<0.05$ versus IL-1 $\beta$ alone; * $\mathrm{p}<0.05$ versus one drug concentration step lower (Wilcoxon signed-rank test).
Budesonide at a concentration of $10^{-10}-10^{-7} \mathrm{M}$ significantly inhibited the IL-1 $\beta$-induced ICAM-1 upregulation (fig. 1a); maximal inhibition was $50 \%[48-52]$ at $10^{-7} \mathrm{M}$. A higher concentration was needed to significantly inhibit the IL-1 $\beta$-induced VCAM-1 upregulation, i.e. $10^{-9}-10^{-7}$ $\mathrm{M}$ budesonide (fig. 1a); maximal inhibition was $61 \%$ (42$69)$ at $10^{-7} \mathrm{M}$. The TNF- $\alpha$-induced ICAM-1 and VCAM1 upregulation (758 and $263 \%$ of baseline, respectively) (fig. 2a), as well as IFN- $\gamma$ induced ICAM-1 upregulation (586\% of baseline) (fig. 3), were significantly inhibited at $\geq 10^{-9} \mathrm{M}$, whereas IL-4-induced VCAM-1 upregulation ( $252 \%$ of baseline) was significantly inhibited at $\geq 10^{-10}$ M (fig. 4). TNF- $\alpha$-stimulated ICAM-1 upregulation was maximally inhibited by $49 \%(46-57)$ and VCAM-1 upregulation by $57 \%(44-68)$ at $10^{-7} \mathrm{M}$. IFN- $\gamma$-induced ICAM-1 upregulation was maximally inhibited by $64 \%$ (41-67) and IL-4-induced VCAM-1 upregulation by $82 \%$ (69-92) at $10^{-7} \mathrm{M}$. The effect on unstimulated fibroblasts was also assessed: basal VCAM-1 expression was significantly reduced by $10^{-9}$ and $10^{-7} \mathrm{M}$ budesonide (maximal reduction to $89 \%(79-95)$ of baseline at $10^{-7} \mathrm{M}$ ), whereas basal ICAM-1 expression was only significantly reduced by $10^{-9} \mathrm{M}$ (reduction to $62 \%$ (47-99) of baseline) (data not shown).
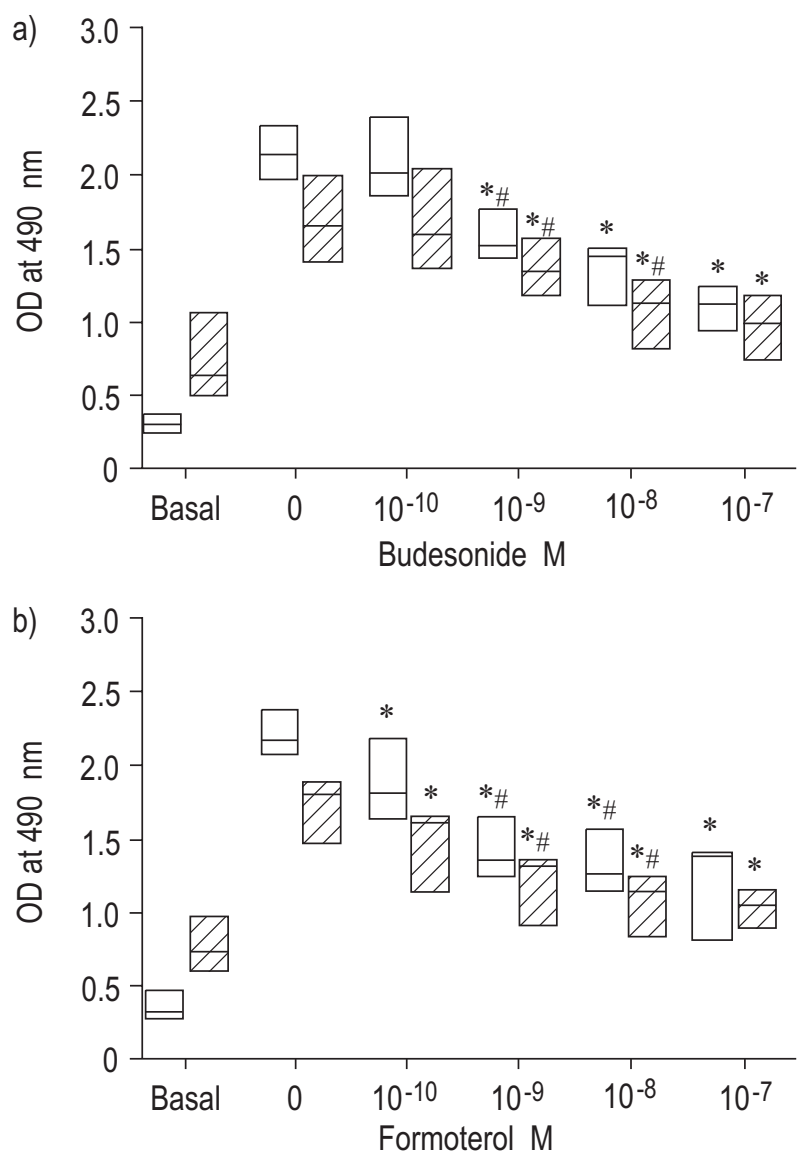

Fig. 2. - Effect of: a) budesonide at $10^{-10}-10^{-7} \mathrm{M}(\mathrm{n}=7)$; and $\left.\mathrm{b}\right)$ formoterol at $10^{-10}-10^{-7} \mathrm{M}(\mathrm{n}=5)$ on the tumour necrosis factor- $\alpha$ (TNF- $\left.\alpha\right)$ nduced intercellular adhesion molecule-1 $(\square)$ and vascular cell adhesion molecule-1 $(\mathbb{Z})$ expression of human lung fibroblasts. Data are presented as median and $25-75 \%$ percentiles after subtraction of isotype control. OD: optical density. ${ }^{*}: \mathrm{p}<0.05$ versus $\mathrm{TNF}-\alpha$ alone; ${ }^{*}: \mathrm{p}<0.05$ versus one drug concentration step lower (Wilcoxon signed-rank test). 


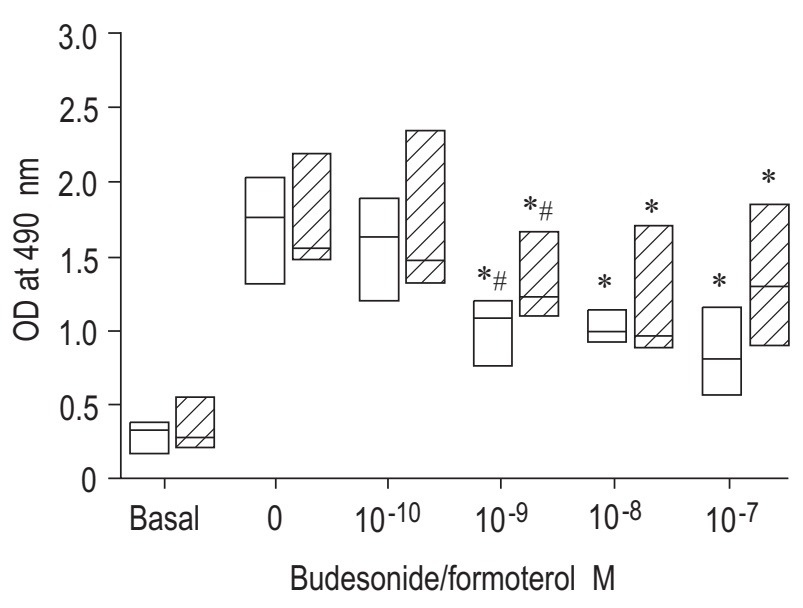

Fig. 3. - Effect of: a) budesonide at $10^{-10}-10^{-7} \mathrm{M}(\square \mathrm{n}=7)$ and formoterol at $10^{-10}-10^{-7} \mathrm{M}(\mathbb{\mathrm { n }}=5)$ on the interferon gamma (IFN- $\gamma$ )-induced intercellular adhesion molecule-1 expression of human lung fibroblasts. Data are presented as median and $25-75 \%$ percentiles after subtraction of isotype control. OD: optical density. *: $\mathrm{p}<0.05$ versus IFN- $\gamma$ alone; ${ }^{\#}$ : $\mathrm{p}<0.05$ versus one drug concentration step lower (Wilcoxon signed-rank test).

Dose-dependent inhibition by budesonide was found for all cytokine stimulations $(\mathrm{p}<0.05$, Friedman test). Between samples significant differences in the extent of inhibition were found between $10^{-10}$ and $10^{-9} \mathrm{M}$ budesonide for the IL- $1 \beta$ - and TNF- $\alpha$-induced ICAM- 1 upregulation, and between $10^{-9}$ and $10^{-8} \mathrm{M}$ for the IL-1 $\beta$ - and TNF- $\alpha$-induced ICAM-1 and VCAM-1 upregulation (figs. 1a and 2a). For IFN- (fig. 3) and IL-4 (fig. 4) stimulation, there was a significant difference in inhibition of ICAM-1 and VCAM-1 upregulation, respectively, between $10^{-10}$ and $10^{-9} \mathrm{M}$. This indicates dose-dependent inhibition by budesonide up to $10^{-8} \mathrm{M}$ for IL- $1 \beta$ and TNF- $\alpha$-induced VCAM- 1 upregulation and up to $10^{-9} \mathrm{M}$ for IL- $1 \beta-$, TNF- $\alpha$, IFN- $\gamma$-induced ICAM-1 and IL4-induced VCAM-1 upregulation. At $10^{-8}$ $M$ budesonide, IL-1 $\beta$ - and TNF- $\alpha$ - induced upregulation of VCAM-1 was significantly more strongly inhibited $(p<0.05)$ than the upregulation of ICAM-1.

\section{Effects of formoterol}

Formoterol significantly inhibited $(\mathrm{p}<0.05)$ ICAM-1 and VCAM-1 upregulation (1061 and $237 \%$ compared to baseline, respectively) induced by IL- $1 \beta$ stimulation at a concentration of $10^{-10}-10^{-7} \mathrm{M}$; maximal inhibition was $55 \%(50-73)$ at $10^{-7} \mathrm{M}$ and $86 \%(64-94)$ at $10^{-8} \mathrm{M}$ (fig. $1 b)$. TNF- $\alpha$-induced ICAM- 1 and VCAM-1 upregulation ( 828 and $253 \%$ of baseline, respectively) were also significantly inhibited $(\mathrm{p}<0.05)$ at a concentration of $10^{-10}-10^{-7}$ $\mathrm{M}$; maximal inhibition was 44\% (40-75) and 62\% (5283 ), respectively, at $10^{-7} \mathrm{M}$ (fig. $2 \mathrm{~b}$ ). The IFN- $\gamma$-induced ICAM-1 upregulation (538\% of baseline) was inhibited at $\geq 10^{-9} \mathrm{M}$; maximal inhibition was $39 \%(29-49)$ at $10^{-8} \mathrm{M}$ (fig. 3), whereas, the IL-4-induced VCAM-1 upregulation (241\% of baseline) was significantly inhibited by $10^{-9}$ and $10^{-7} \mathrm{M}$ formoterol; maximal inhibition was $43 \%$ (3367 ) at $10^{-7} \mathrm{M}$ (fig. 4). Basal expression of ICAM-1 and VCAM-1 on unstimulated fibroblasts was also significantly reduced by $10^{-9}-10^{-7} \mathrm{M}$ formoterol; maximal re-

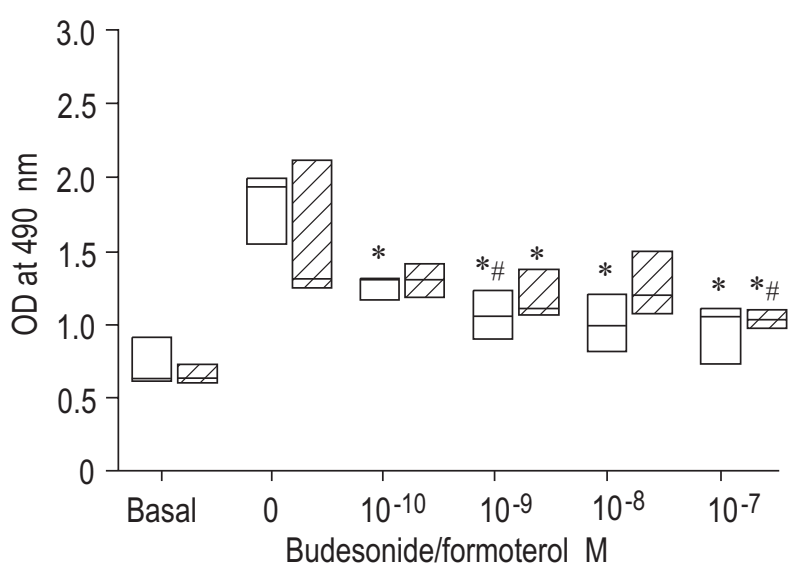

Fig. 4. - Effect of budesonide at $10^{-10}-10^{-7} \mathrm{M}(\square \mathrm{n}=5)$ and formoterol at $10^{-10}-10^{-7} \mathrm{M}(\mathbb{Z} \mathrm{n}=7)$ on the interleukin (IL)-4-induced vascular cell adhesion molecule-1 expression of human lung fibroblasts. Data are presented as median and $25-75 \%$ percentiles after subtraction of isotype control. OD: optical density. *: $\mathrm{p}<0.05$ versus IL-4 alone; ${ }^{\#}: \mathrm{p}<0.05$ versus one drug concentration step lower (Wilcoxon signed-rank test).

duction was to 57 (51-67) and 84\% (76-88) of baseline, respectively, at $10^{-7} \mathrm{M}$.

There was a dose-response relationship for the inhibition by formoterol of all cytokine stimulations $(p<0.05$, Friedman test). Between samples, significant differences were observed in the extent of inhibition by formoterol between $10^{-10}$ and $10^{-9} \mathrm{M}$ for the IL-1 $\beta$ - (fig. $1 \mathrm{~b}$ ) as well as the TNF- $\alpha$-induced (fig. 2b) ICAM-1 and VCAM-1 upregulation. There were also significant differences between the extent of inhibition by $10^{-9}$ and $10^{-8} \mathrm{M}$ formoterol of the TNF-a-induced ICAM-1 upregulation and of the IL$1 \beta$ - and TNF- $\alpha$-induced VCAM- 1 upregulation. For IFN- $\gamma$ stimulation, there was a significant difference in inhibition by formoterol of ICAM-1 upregulation between $10^{-10}$ and $10^{-9} \mathrm{M}$ (fig. 3). For IL-4 stimulation, there was a significant difference in inhibition of VCAM1 upregulation between $10^{-7}$ and $10^{-8} \mathrm{M}$ (fig. 4). This indicates a dose-dependent inhibition by formoterol up to $10^{-8} \mathrm{M}$ for IL- $1 \beta$-induced VCAM- 1 and TNF- $\alpha$-induced ICAM-1 and VCAM-1 upregulation and up to $10^{-9} \mathrm{M}$ for IL-1 $\beta$ - and IFN-g-induced ICAM-1 upregulation. All concentrations of formoterol inhibited VCAM-1 upregulation significantly more strongly than ICAM-1 upregulation after IL-1 $\beta$ and TNF- $\alpha$ stimulation (table 1). Formoterol displayed stronger inhibition than budesonide of VCAM-1 upregulation, especially after IL-1 $\beta$ stimulation (table 1). In contrast, budesonide tended to be stronger than formoterol in inhibiting ICAM-1 or VCAM-1 upregulation after IFN- $\gamma$ and IL-4 stimulation, respectively.

\section{Discussion}

ICAM-1 and VCAM-1 are important adhesion molecules in asthma with regard to infiltration of inflammatory cells into the lung. The present study shows that the glucocorticoid budesonide and the long-acting $\beta_{2}$-agonist formoterol both inhibit IL-1 $\beta$-, TNF- $\alpha-$, IFN- $\gamma$ - and IL-4induced ICAM-1 and VCAM-1 upregulation on human lung fibroblasts. Moreover, a small reduction in basal ICAM-1 and VCAM-1 levels by both drugs was also found. 
Table 1. - Inhibitory effects of budesonide and formoterol on the intercellular adhesion molecule-1 (ICAM-1) and vascular cell adhesion molecule-1 (VCAM-1) expression of human lung fibroblasts stimulated with interleukin (IL)$1 \beta$, tumour necrosis factor- $\alpha$ (TNF- $\alpha$ ), interferon gamma (IFN- $\gamma$ ) or IL-4

\begin{tabular}{lccl}
\hline & $\begin{array}{c}\text { Drug con- } \\
\text { centration } \\
\mathrm{M}\end{array}$ & Budesonide & Formoterol \\
\hline ICAM-1/IL-1 $\beta$ & $10^{-10}$ & $7(2-14)$ & $10(9-21)$ \\
& $10^{-9}$ & $33(26-43)$ & $47(41-53)^{*}$ \\
& $10^{-8}$ & $48(37-56)$ & $49(47-56)$ \\
VCAM-1/IL-1 $\beta$ & $10^{-7}$ & $50(48-52)$ & $55(50-73)$ \\
& $10^{-10}$ & $-11(-19-4)^{\#}$ & $29(22-50)^{* \#}$ \\
& $10^{-9}$ & $38(13-50)$ & $72(61-86)^{*}, \#$ \\
ICAM-1/TNF- $\alpha$ & $10^{-8}$ & $57(50-75)^{\#}$ & $86(64-94)^{*}, \#$ \\
& $10^{-7}$ & $61(42-69)$ & $80(69-105)^{\#}$ \\
& $10^{-10}$ & $-4(3-14)$ & $13(9-27)$ \\
VCAM-1/TNF- $\alpha$ & $10^{-9}$ & $36(28-36)$ & $43(34-47)$ \\
& $10^{-8}$ & $42(33-54)$ & $45(37-54)$ \\
& $10^{-7}$ & $49(46-57)$ & $44(40-75)$ \\
& $10^{-10}$ & $-3(22-5)^{\#}$ & $28(15-39)^{*}, \#$ \\
ICAM-1/IFN- $\gamma$ & $10^{-9}$ & $30(23-44)$ & $52(46-63)^{\#}$ \\
& $10^{-8}$ & $56(44-69)^{\#}$ & $62(59-71)^{\#}$ \\
& $10^{-7}$ & $57(44-68)$ & $62(52-83)^{\#}$ \\
& $10^{-10}$ & $6(-5-17)$ & $11(-14-15)$ \\
& $10^{-9}$ & $53(38-58)$ & $31(23-34)$ \\
VCAM-1/IL-4 & $10^{-8}$ & $58(45-66)$ & $39(29-49)$ \\
& $10^{-7}$ & $64(41-67)$ & $22(9-50)$ \\
& $10^{-10}$ & $26(17-63)$ & $12(1-45)$ \\
& $10^{-9}$ & $73(47-84)$ & $34(11-58)$ \\
& $10^{-8}$ & $80(66-81)$ & $31(-3-48)$ \\
& $10^{-7}$ & $82(69-92)$ & $43(33-67)$ \\
\hline
\end{tabular}

Data are presented as median $(25-75 \%$ percentiles $) *: p<0.05$ compared to inhibition by budesonide; ${ }^{\text {\# }}: \mathrm{p}<0.05$ compared to inhibition of ICAM-1 expression.

Concentrations of budesonide $10^{-10}-10^{-8} \mathrm{M}$ have been considered to be of clinical relevance, since in vivo concentrations range from $10^{-9} \mathrm{M}$ in blood to $10^{-8} \mathrm{M}$ in lung tissue, $90 \mathrm{~min}$ after a single inhaled dose of 1,600 $\mu \mathrm{g}$ [29]. This is the first study showing that budesonide in clinically relevant doses inhibits ICAM-1 and VCAM-1 expression on human lung fibroblasts in a dose-dependent way in all cytokine-stimulated conditions. This finding is compatible with similar results obtained using an epithelial cell line in which budesonide $\left(10^{-8}\right.$ inhibited the basal expression and the IFN- $\gamma$-induced upregulation of ICAM-1 [6]. The observed in vitro inhibition of inflammatory cytokine-induced adhesion molecule expression by budesonide on human lung fibroblasts is in agreement with the reduced eosinophil influx observed in asthmatic patients after budesonide treatment [1]. The underlying mechanisms of the inhibitory activity of glucocorticoids have been extensively described. Glucocorticoid bound to the glucocorticoid receptor can interact with various transcription factors, preventing attachment of these factors to their binding sequences on the promoters of several genes. These transcription factors are necessary for the induction of several messenger ribonucleic acids by cytokine.stimulation. Glucocorticoids can also inhibit the transcription factor nuclear factor- $\kappa \mathrm{B}(\mathrm{NF} \kappa \mathrm{B})$ by inducing expression of its inhibitory factor inhibitory- $\kappa \mathrm{B}[30]$. The ICAM-1 and VCAM-1 gene both contain activating protein-1 (AP-1) and NFאB binding sites, providing modulatory sites for glucocorticoids [31-34].

To the authors' knowledge, this is the first report of the inhibitory action of the $\beta_{2}$-agonist formoterol on ICAM-1 and VCAM-1 upregulation on resident lung cells, such as fibroblasts. Formoterol dose-dependently inhibited the IL$1 \beta-$, TNF- $\alpha-$, IFN- $\gamma-$ and IL-4-induced upregulation of ICAM-1 and/or VCAM-1 on human lung fibroblasts. In support of these results, several studies have shown inhibition of granulocyte adhesion to endothelium or epithelium by other long-acting $\beta_{2}$-agonists $[17,35]$. This phenomenon could not be fully explained in these studies, although it was thought to be primarily an effect on the endothelial or epithelial cells. It is thus very likely that the antiadhesive effect of $\beta_{2}$-agonists in those studies was caused by modulation of adhesion molecule expression on endothelial and epithelial cells, as shown for fibroblasts in the present study. $\beta_{2}$-agonists can act via binding to $\beta_{2}$-adrenoceptors, which are also present on fibroblasts [36]. Downregulation of ICAM-1 expression by the shortacting $\beta_{2}$-agonist fenoterol has been described in epithelial cells [37]. Signalling by $\beta_{2}$-adrenoceptors is via the adenylate cyclase pathway, increasing intracellular cAMP and eventually activating cAMP-responsive element binding protein (CREB) [10]. The activated CREB is able to interact with transcription factors, such as AP-1, thereby inhibiting gene transcription [38]. Another study has shown direct cAMP involvement in cytokine-induced ICAM-1 and VCAM-1 upregulation in smooth muscle cells [39]. Therefore, it is possible that formoterol also modulates adhesion molecule upregulation at this level on fibroblasts. Formoterol has been detected in plasma samples at a concentration of $2.5 \times 10^{-10} \mathrm{M} 1 \mathrm{~h}$ after inhalation of a $120-\mu \mathrm{g}$ dose [40], which is six times higher than a conventional dose. No results are available regarding concentrations reached in lung tissue, but locally higher concentrations may very well be present after regular inhaled doses. In guinea-pig models, eosinophil influx into the lungs after challenge was inhibited by formoterol $[11,16]$. In humans, there is also evidence for direct inhibitory effects on mast cell and eosinophil infiltration in vivo after inhaled formoterol therapy [15]. This could be due, in part, to decreased expression of adhesion molecules by lung fibroblasts, thus contributing to the reduction in asthmatic inflammation.

VCAM- 1 upregulation was more strongly inhibited by formoterol than ICAM-1 upregulation after IL- $1 \beta$ and TNF- $\alpha$ stimulation and to a lesser extent by budesonide under these particular experimental conditions. Formoterol tended to inhibit VCAM-1 upregulation more strongly than did budesonide after IL- $1 \beta$ and TNF- $\alpha$ stimulation, whereas budesonide more strongly inhibited IFN- $\gamma$-induced ICAM-1 and IL-4- induced VCAM-1 upregulation. This may be explained by differences in the molecular mechanisms of the drugs, as well as different signal transduction pathways of the cytokines. Overall, budesonide and formoterol were both able to inhibit ICAM-1 and VCAM-1 upregulation, which effect was not dependent on the type of cytokine stimulus used in this study. It would be interesting to know the combined effect of these drugs, since they are often used in asthma therapy simultaneously, and especially because cAMP pathways are able to interact with glucocorticoid receptor pathways at different levels 
$[41,42]$. This issue is currently under investigation in the authors' laboratory.

In conclusion, both budesonide (at therapeutically relevant doses) and formoterol (possibly at therapeutically relevant doses) inhibit interleukin-1 $\beta$-, tumour necrosis factor- $\alpha$-, interferon gamma- and interleukin- 4 induced upregulation of the adhesion molecules intercellular adhesion molecule-1 and vascular cell adhesion molecule-1 on human lung fibroblasts. The authors hypothesize that the beneficial effects of inhaled budesonide and inhaled formoterol in asthma could be due, in part, to modulation of the expression of adhesion molecules on resident cells in the lung. tissue, thus diminishing infiltration and/or retention of inflammatory cells.

Acknowledgements. The authors thank $M$ Boorsma for critically reading the manuscript

\section{References}

1. Gauvreau GM, Doctor J, Watson RM, Jordana M, O'Byrne PM. Effects of inhaled budesonide on allergen-induced airway responses and airway inflammation. Am J Respir Crit Care Med 1996; 154: 1267-1271.

2. Oddera S, Silvestri M, Sacco O, Lantero S, Morelli MC, Rossi GA. Evaluation of the inhibitory effects of budesonide on the mitogen-induced or the allergen-induced activation of blood mononuclear cells isolated from asthmatic patients. Ann Allergy Asthma Immunol 1995; 75: 33-40.

3. Linden M, Brattsand R. Effects of a corticosteroid, budesonide, on alveolar macrophage and blood monocyte secretion of cytokines: differential sensitivity of GM-CSF, IL-1ß, and IL-6. Pulm Pharmacol 1994; 7: 43-47.

4. Miyamasu M, Misaki Y, Izumi S, et al. Glucocorticoids inhibit chemokine generation by human eosinophils. $J$ Allergy Clin Immunol 1998; 101: 75-83.

5. Mullol J, Xaubet A, Lopez E, Roca-Ferrer J, Picado C. Comparative study of the effects of different gluco'corticosteroids on eosinophil survival primed by cultured epithelial cell supernatants obtained from nasal mucosa and nasal polyps. Thorax 1995; 50: 270-274.

6. Paolieri F, Battifora M, Riccio AM, et al. Inhibition of adhesion molecules by budesonide on a human epithelial cell line (lung carcinoma). Allergy 1997; 52: 935-943.

7. Wheller SK, Perretti M. Dexamethasone inhibits cytokine-induced intercellular adhesion molecule-1 up-regulation on endothelial cell lines. Eur J Pharmacol 1997; 331: 65-71.

8. John M, Hirst SJ, Jose PJ, et al. Human airway smooth muscle cells express and release RANTES in response to T helper 1 cytokines: regulation by T helper 2 cytokines and corticosteroids. J Immunol 1997; 158: 1841-1847.

9. Tobler A, Meier R, Seitz M, Dewald B, Baggiolini M, Fey MF. Glucocorticoids downregulate gene expression of GM-CSF, NAP-1/IL-8, and IL-6, but not of M-CSF in human fibroblasts. Blood 1992; 79: 45-51.

10. Barnes PJ. Beta-adrenergic receptors and their regulation. Am J Respir Crit Care Med 1995; 152: 838-860.

11. Eda R, Sugiyama H, Hopp RJ, Okada C, Bewtra AK, Townley RG. Inhibitory effects of formoterol on plateletactivating factor induced eosinophil chemotaxis and degranulation. Int Arch Allergy Immunol 1993; 102: 391-398.

12. Mita H, Shida T. Anti-allergic activity of formoterol, a new beta-adrenoceptor stimulant, and salbutamol in human leukocytes and human lung tissue. Allergy 1983; 38: $547-552$.
13. Palmqvist M, Balder B, Lowhagen O, Melander B, Svedmyr N, Wahlander L. Late asthmatic reaction decreased after pretreatment with salbutamol and formoterol, a new long-acting beta 2-agonist. J Allergy Clin Immunol 1992; 89: 844-849.

14. Wong BJ, Dolovich J, Ramsdale EH, et al. Formoterol compared with beclomethasone and placebo on allergeninduced asthmatic responses. Am Rev Respir Dis 1992; 146: 1156-1160.

15. Wallin A, Sandstrom T, Soderberg M, et al. The effects of regular inhaled formoterol, budesonide, and placebo on mucosal inflammation and clinical indices in mild asthma. Am J Respir Crit Care Med 1999; 159: 79-85.

16. Sugiyama H, Okada C, Bewtra AK, Hopp RJ, Townley RG. The effect of formoterol on the late asthmatic phenomena in guinea pigs. J Allergy Clin Immunol 1992; 89: 858-866.

17. Bowden JJ, Sulakvelidze I, McDonald DM. Inhibition of neutrophil and eosinophil adhesion to venules of rat trachea by beta 2-adrenergic agonist formoterol. J Appl Physiol 1994; 77: 397-405.

18. Carroll N, Cooke C, James A. The distribution of eosinophils and lymphocytes in the large end small airways of asthmatics. Eur Respir J 1997; 10: 292-300.

19. Hamid Q, Song YL, Kotsimbos TC, et al. Inflammation of small airways in asthma. J Allergy Clin Immunol 1997; 100: 44-51.

20. Tobler A, Meier R, Seitz M, Dewald B, Baggiolini M, Fey MF. Glucocorticoids downregulate gene expression of GM-CSF, NAP-1/IL-8, and IL-6, but not of M-CSF in human fibroblasts. Blood 1992; 79: 45-51.

21. Noso N, Sticherling M, Bartels J, Mallet AI, Christophers E, Schröder JM. Identification of an N-terminally truncated form of the chemokine RANTES and granulocytemacrophage colony stimulating factor as major eosinophil attractants released by cytokine-stimulated dermal fibroblasts. J Immunol 1996; 156: 1946-1953.

22. Schlaak JF, Schwarting A, Knolle P, Meyer zum Buschenfelde KH, Mayet W. Effects of Th1 and Th2 cytokines on cytokine production and ICAM-1 expression on synovial fibroblasts. Ann Rheum Dis 1995; 54: 560-565.

23. Spoelstra FM, Postma DS, Hovenga H, Noordhoek JA, Kauffman HF. Interferon- $\gamma$ and interleukin-4 differentially regulate ICAM-1 and VCAM-1 expression on human lung fibroblasts. Eur Respir J 1999; 14: 759-766.

24. Morzycki W, Issekutz AC. Tumour necrosis factor-alpha but not interleukin-1 induces polyrnorphonuclear leucocyte migration through fibroblast layers by a fibroblastdependent mechanism. Immunology 1991; 74: 107-113.

25. Tessier PA, Cattaruzzi P, McColl SR. Inhibition of lymphocyte adhesion to cytokine-activated synovial fibroblasts by glucocorticoids involves the attenuation of vascular cell adhesion molecule 1 and intercellular adhesion molecule 1 gene expression. Arthritis Rheum 1996; 39: 226-234.

26. Takafuji S, Shoji S, Ito K, Yamamoto K, Nakagawa T. Eosinophil degranulation in the presence of lung fibroblasts. Int Arch Allergy Immunol 1998; 117: 52-54.

27. Nakajima H, Sano H, Nishimura T, Yoshida S, Iwamoto I. Role of vascular adhesion molecule 1/very late activation antigen 4 and intercellular adhesion molecule 1/lymphocyte function-association antigen 1 interactions in antigen-induced eosinophil and $\mathrm{T}$ cell recruitment into the tissue. J Exp Med 1994; 179: 1145-1154.

28. Piela Smith TH, Broketa G, Hand A, Korn JH. Regulation of ICAM-1 expression and function in human dermal fibroblasts by IL-4. J Immunol 1992; 148: 1375-1381. 
29. Van den Bosch JM, Westermann CJ, Aumann J, Edsbacker S, Tonnesson M, Selroos O. Relationship between lung tissue and blood plasma concentrations of inhaled budesonide. Biopharm Drug Dispos 1993; 14: 455-459.

30. Scheinman RI, Cogswell PC, Lofquist AK, Baldwin AS Role oftranscriptional activation of I kappa B alpha in mediation of immunosuppression by glucocorticoids. Science 1995; 270: 283-286.

31. Van der Saag PT, Caldenhoven E, Van de Stolpe A. Molecular mechanisms of steroid action: a novel type of cross-talk between glucocorticoids and NF-kappa B transcription factors. Eur Respir $J$ Suppl. 1996; 22: $146 \mathrm{~s}-153 \mathrm{~s}$

32. Van de Stolpe A, Van der Saag PT. Intercellular adhesion molecule-1. J Mol Med 1996; 74: 13-33.

33. Ahmad M, Theofanidis P, Medford RM. Role of activating protein-1 in the regulation of the vascular cell adhesion molecule-1 gene expression by tumor necrosis factor-a. J Biol Chem 1998; 273: 4616-4621.

34. Lockyer JM, Colladay JS, Alperin-Lea WL, Hammond T, Buda AJ. Inhibition of nuclear factor-kappaB-mediated adhesion molecule expression in human endothelial cells. Circ Res 1998; 82: 314-320.

35. Bloemen PGM, van den Tweel MC, Henricks PAJ, et al. Increased cAMP levels in stimulated neutrophils inhibit their adhesion to human bronchial epithelial cells. Am J Physiol Lung Cell Mol Physiol 1997; 272: L580-L587.

36. Kilfeather SA, Collins D, McCormack P, Cotter T, $\mathrm{O}^{\prime}$ Malley $\mathrm{K}$. The effect of in vitro aging on human lung fibroblast beta-adrenergic receptor density, coupling and response. Mech Ageing Dev 1992; 63: 247-256.

37. Oddera S, Silvestri M, Lantero S, Sacco O, Rossi GA. Downregulation of the expression of intercellular adhesion molecule (ICAM)-1 on bronchial epithelial cells by fenoterol, a $\beta_{2}$-adrenoceptor agonist. J Asthma 1998; 35: 401-408.

38. Masquilier D, Sassone CP. Transcriptional cross-talk: nuclear factors CREM and CREB bind to AP-1 sites and inhibit activation by Jun. J Biol Chem 1992; 267: 22460 22466.

39. Braun M, Pietsch P, Zepp A, Schrör K, Baumann G, Felix SB. Regulation of tumour necrosis factor- $\alpha$ and interleukin-1 $\beta$ induced adhesion molecule expression in human vascular smooth muscle cells by cAMP. Arterioscler Thromb Vasc Biol 1997; 17: 2568-2575.

40. Campestrini J, Lecaillon JB, Godbillon J. Automated and sensitive method for the determination of formoterol in human plasma by high-performance liquid chromatography and electrochemical detection. $J$ Chromatogr $B$ Biomed Sci Appl 1997; 704: 221-229.

41. Penuelas I, Encio IJ, Lopez-Moratalla N, Santiago E. cAMP activates transcription of the human glucocorticoid receptor gene promoter. J Steroid Biochem Mol Biol 1998: 67: 89-94.

42. Eickelberg O, Roth M, Lörx R, et al. Ligand-independent activation of the glucocorticoid receptor by $\beta_{2}$-adrenergic receptor agonists in primary human lung fibroblasts and vascular smooth muscle cells. J Biol Chem 1999; 274: $1005-1010$. 